\title{
Microsomal epoxide hydrolase polymorphisms
}

\author{
HATICE PINARBASI ${ }^{1}$, YAVUZ SILIG $^{1}$ and ERGUN PINARBASI ${ }^{2}$ \\ Departments of ${ }^{1}$ Biochemistry, and ${ }^{2}$ Medical Biology, Faculty of Medicine, Cumhuriyet University, 58140 Sivas, Turkey
}

Received March 30, 2010; Accepted June 6, 2010

DOI: $10.3892 / \mathrm{mmr}+00000324$

\begin{abstract}
Microsomal epoxide hydrolase plays a dual role in the activation and detoxification of carcinogenic compounds. Two polymorphic sites have been described in exons 3 and 4 of the microsomal epoxide hydrolase gene that change tyrosine residue 113 to histidine (Tyr113His) and histidine 139 to arginine (His139Arg), respectively. The exon 3 polymorphism reduces enzyme activity by approximately $50 \%$, whereas the exon 4 polymorphism causes a $25 \%$ increase in activity. In the present study, the distribution of these polymorphisms in a Turkish population including 625 unrelated healthy individuals was examined using a PCR-RFLP method. The observed genotype frequencies of microsomal epoxide hydrolase exon 3 were 54, 38 and 8\% for Tyr113Tyr, Tyr113His and His113His, respectively. Exon 4 genotype frequencies were found to be 69, 29 and $2 \%$ for His139His, His139Arg and Arg139Arg, respectively.
\end{abstract}

\section{Introduction}

Epoxides are chemically reactive compounds and are unstable in an aqueous environment. They arise from the oxidative metabolism of xenobiotics and also from endogenous compounds via the cytochrome P450 monooxygenase system. Epoxide intermediates are known to be mutagenic and carcinogenic (1). The epoxide hydrolases catalyse the hydration of reactive epoxides to their corresponding dihydrodiol species. In general, this mechanism makes the intermediates more stable and less reactive (2). It has been reported that the mammalian microsomal epoxide hydrolase $(\mathrm{mEH})$ plays a key role in xenobiotic metabolism. The main function of $\mathrm{mEH}$ is the breakdown of genotoxic and carcinogenic epoxides to less harmful metabolites and the protection of macromolecules from the electrophilic attack of reactive intermediates (3). However, in the case of some polycyclic aromatic hydrocarbons, such as benzo(a)pyrene, present in tobacco smoke, dihydrodiol formation stabilizes bay-region epoxides, increasing the mutagenic and carcinogenic potential of the product $(4,5)$. Therefore, $\mathrm{mEH}$ plays a dual role in the detoxification and the bioactivation of some procarcinogens. $\mathrm{mEH}$ is expressed

Correspondence to: Dr Hatice Pinarbasi, Department of Biochemistry, Faculty of Medicine, Cumhuriyet University, 58140 Sivas, Turkey E-mail: hpinar2658@gmail.com

Key words: microsomal epoxide hydrolase, polymorphism in all tissues, with the highest levels of $\mathrm{mEH}$ activity being detected in the liver, kidney and testis $(6,7)$. The human $\mathrm{mEH}$ enzyme is encoded by a single gene that has been localized to 1p11-qter (8). The gene and cDNA for $\mathrm{mEH}$ has been cloned and sequenced in humans $(8,9)$. The gene consists of eight non-coding exons and one coding exon, and encodes for a 455 amino acid protein (9). In the coding region of the $\mathrm{mEH}$ gene, two polymorphisms have been identified. In exon 3 a $T \rightarrow C$ mutation changes tyrosine residue 113 to histidine (Tyr113His). This substitution decreases enzyme activity by approximately $50 \%$ (slow activity genotype). The exon 4 polymorphism, a $\mathrm{G} \rightarrow \mathrm{A}$ transition, causes a histidine to arginine change at codon 139 resulting in a $25 \%$ increase in enzyme activity (10). $\mathrm{mEH}$ polymorphisms may lead to differences in the metabolism of carcinogens, resulting in altered susceptibility to some types of cancer (11-13). Two meta-analyses indicated that a low activity genotype (exon 3 His113His) is associated with a decreased risk of lung cancer $(14,15)$. Population information on polymorphisms is essential for the study of genetic diseases. The aim of this study was to determine the frequencies of the two polymorphisms of the $\mathrm{mEH}$ gene in a Turkish population, including 625 healthy individuals. The results will be a basis for molecular epidemiological studies investigating the association between polymorphisms in biotransformation enzymes and chemically-induced cancer risk.

\section{Materials and methods}

Subjects. The study population included 625 unrelated healthy Turkish volunteers from central Anatolia with no previous cancer or chronic disease. All participants gave their informed consent and completed a short questionnaire to determine their occupation, tobacco use, alcohol consumption and family history of cancer. The local university ethics committee on human research approved the study.

Genotype determination. Peripheral blood samples $(2 \mathrm{ml})$ were collected into citrate containing tubes from all subjects. DNA was extracted from whole blood using a salting out procedure as soon as the samples reached the laboratory (16). The isolated DNA was stored at $-20^{\circ} \mathrm{C}$ until use. Genetic polymorphisms in $\mathrm{mEH}$ exons 3 and 4 were determined using a PCR-RFLP.

Determination of the exon 3 polymorphism. The following primers were used to amplify a 163-bp fragment of exon 3: 5' GATCGATAAGTTCCGTTTCACC 3' and 5' ATCTTA GTCTTGAAGTGAGGAT 3'. PCR was performed in a 50- $\mu 1$ 


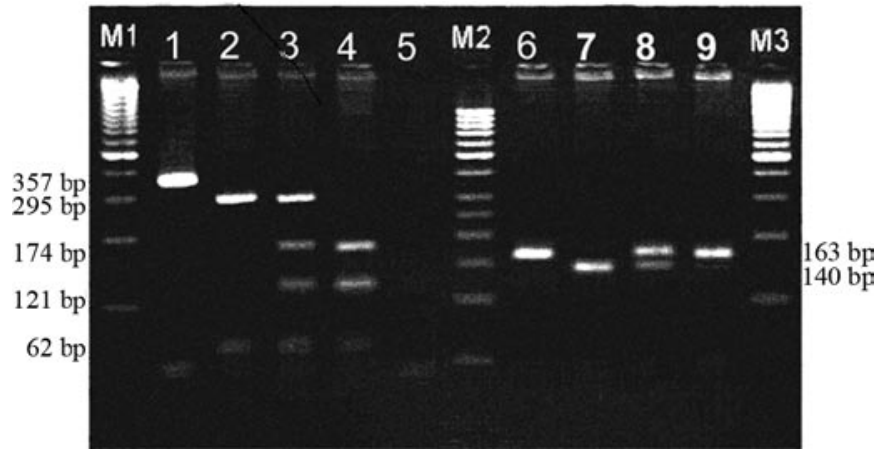

Figure 1. PCR-RFLP patterns of polymorphisms of mEH exons 3 and 4 M1: gene ruler 100-bp DNA ladder; 1, exon 4 PCR product; 2, His139His; 3, His139Arg; 4, Arg139Arg; 5, negative control. M2: gene ruler 50-bp DNA ladder; 6, exon 3 PCR product; 7, Tyr113Tyr; 8, Tyr113His; 9, His113His.

Table I. Characteristics of the study population.

\begin{tabular}{lc}
\hline Sample size & 625 \\
Gender $(\%)$ & \\
Male & $280(45 \%)$ \\
Female & $345(55 \%)$ \\
Age (years) & \\
Range & $21-81$ \\
Mean \pm SD & $51.2 \pm 14.6$ \\
Male & $59.4 \pm 8.73$ \\
Female & $44.5 \pm 15.0$
\end{tabular}

reaction mixture containing 75 pmol of the primers, $200 \mathrm{ng}$ DNA, $0.2 \mathrm{mM}$ dNTPs, $2 \mathrm{mM} \mathrm{MgCl}_{2}$ and 2.5 units Taq DNA polymerase. After an initial denaturation at $94^{\circ} \mathrm{C}$ for $5 \mathrm{~min}$, the DNA was amplified by 35 cycles of $30 \mathrm{sec}$ at $94^{\circ} \mathrm{C}, 20 \mathrm{sec}$ at $56^{\circ} \mathrm{C}$ and $20 \mathrm{sec}$ at $72^{\circ} \mathrm{C}$, followed by a final extension of $7 \mathrm{~min}$ at $72^{\circ} \mathrm{C}$. The amplified products were digested overnight with EcoRV restriction enzyme at $37^{\circ} \mathrm{C}$. EcoRV digestion produced 140- and 23-bp fragments of the wild-type genotype, while the polymorphic homozygous type remained undigested (Fig. 1).

Determination of the exon 4 polymorphism. A 357-bp DNA fragment in exon 4 was amplified using the primers $5^{\prime}$ GGGGTACCAGAGCCTGACCGT 3' and 5' AACACCGGG CCCACCCTTGGC 3'. The incubation mixture was the same as that used for the amplification of the exon 3 target sequence. The cycling protocol included initial denaturation at $94^{\circ} \mathrm{C}$ for $5 \mathrm{~min}$ and 35 cycles of $94^{\circ} \mathrm{C}$ for $30 \mathrm{sec}, 63^{\circ} \mathrm{C}$ for $30 \mathrm{sec}$ and $72^{\circ} \mathrm{C}$ for $45 \mathrm{sec}$, followed by a final extension of $7 \mathrm{~min}$ at $72^{\circ} \mathrm{C}$. Digestion of the amplified product overnight with $R s a$ I restriction endonuclease at $37^{\circ} \mathrm{C}$ produced 295- and 62-bp fragments of the wild-type genotype, and 174-, 121- and 62-bp fragments of the homozygous polymorphic genotype (Fig. 1).

\section{Results}

In the present study, 625 (280 men and 345 women) Turkish individuals were genotyped for polymorphisms of exons 3 and
Table II. Genotype frequencies for $\mathrm{mEH}$ exon 3 polymorphism.

\begin{tabular}{lrcc}
\hline Genotype & No. & Percentage & p-value \\
\hline Total & 625 & & \\
Tyr113Tyr & 338 & 54 & \\
Tyr113His & 235 & 38 & 0.22 \\
His113His & 52 & 8 & \\
\hline
\end{tabular}

${ }^{\mathrm{a}}$ For Hardy-Weinberg equilibrium; $\chi^{2}=1.49$.

Table III. Genotype frequencies for $\mathrm{mEH}$ exon 4 polymorphism.

\begin{tabular}{lccc}
\hline Genotype & No. & Percentage & p-value \\
\hline Total & 601 & & \\
His 139His & 418 & 69 & \\
His139Arg & 174 & 29 & 0.054 \\
Arg139Arg & 9 & 2 & \\
\hline FFor Hardy-Weinberg equilibrium; $\chi^{2}=3.7$. & \\
\hline
\end{tabular}

4 in the $\mathrm{mEH}$ gene. The principal characteristics of the study population are listed in Table I. The mean age of the study population was $51.2 \pm 14.6$ years (males, 59.4 \pm 8.73 ; females, $44.5 \pm 15.0$ ). The observed genotype frequencies of $\mathrm{mEH}$ are summarized in Tables II and III. In the EcoRV-RFLP analysis of exon 3, 54\% Tyr113Tyr genotype, 38\% Tyr113His genotype and $8 \%$ His113His genotype were determined (Table II). According to the RsaI-RFLP analysis of exon 4, genotype frequencies were 69, 29 and $2 \%$ for His139His, His139Arg and Arg139Arg, respectively (Table III). The genotype distributions were in Hardy-Weinberg equilibrium for Tyr113His $(p=0.22)$ and His139Arg $(p=0.054)$ (Tables II and III). Tables IV and V respectively compare the genotype frequencies of exons 3 and 4 in previously reported populations with those of the present study.

\section{Discussion}

The aim of this study was to investigate the frequencies of polymorphisms of exons 3 and 4 in the $\mathrm{mEH}$ gene, which display ethnic differences, in a Turkish population. The results were compared to those from previously published results from populations of other countries. As seen in Table IV, our sample size was much larger than those of other studies, which is very important for the making of more precise estimations in epidemiological studies. There is wide interethnic variation of the mEH exon 3 polymorphism (His113His), ranging from $6 \%$ in Germans (17) to as high as $42 \%$ in South Koreans (18). The data presented here show that the Turkish population has the same frequencies as Spanish (19), Swedish (20) and Dutch (21) populations and similar frequencies as Slovak, Canadian, Austrian, British (22-25) and German populations (17). We detected considerably lower frequencies than those found in 
Table IV. Distribution of mEH exon 3 genotype frequencies in different populations.

\begin{tabular}{|c|c|c|c|c|c|}
\hline \multirow[t]{2}{*}{ Country } & \multirow[t]{2}{*}{ No. } & \multicolumn{3}{|c|}{ Exon $3(\%)$} & \multirow[t]{2}{*}{ Ref. } \\
\hline & & $\begin{array}{l}\text { Wild-type } \\
\text { Tyr113Tyr }\end{array}$ & $\begin{array}{c}\text { Heterozygous } \\
\text { Tyr113His }\end{array}$ & $\begin{array}{c}\text { Homozygous } \\
\text { His113His }\end{array}$ & \\
\hline Canada & 45 & 47 & 44 & 9 & 23 \\
\hline Spain & 203 & 46 & 46 & 8 & 19 \\
\hline Austria & 496 & 45 & 44 & 11 & 24 \\
\hline United Kingdom & 257 & 50 & 39 & 11 & 25 \\
\hline Japan & 114 & 26 & 45 & 29 & 26 \\
\hline South Korea & 76 & 26 & 32 & 42 & 18 \\
\hline Finland & 115 & 45 & 41 & 14 & 31 \\
\hline France & 105 & 47 & 37 & 16 & 30 \\
\hline Germany & 119 & 52 & 44 & 4 & 17 \\
\hline Italy & 99 & 48 & 37 & 15 & 29 \\
\hline Sweden & 283 & 53 & 39 & 8 & 20 \\
\hline Czech Republic & 447 & 42 & 41 & 17 & 28 \\
\hline Netherland & 391 & 50 & 42 & 8 & 21 \\
\hline China & 266 & 44 & 38 & 18 & 27 \\
\hline Slovakia & 160 & 49 & 42 & 9 & 22 \\
\hline Turkey & 133 & 50 & 42 & 8 & 32 \\
\hline Turkey & 625 & 54 & 38 & 8 & This study \\
\hline
\end{tabular}

Table V. Distribution of mEH exon 4 genotype frequencies in different populations.

\begin{tabular}{|c|c|c|c|c|c|}
\hline \multirow[t]{2}{*}{ Country } & \multirow[t]{2}{*}{ No. } & \multicolumn{3}{|c|}{ Exon $4(\%)$} & \multirow[t]{2}{*}{ Ref. } \\
\hline & & $\begin{array}{l}\text { Wild-type } \\
\text { His 139His }\end{array}$ & $\begin{array}{l}\text { Heterozygous } \\
\text { His139Arg }\end{array}$ & $\begin{array}{l}\text { Homozygous } \\
\text { Arg139Arg }\end{array}$ & \\
\hline Canada & 45 & 76 & 18 & 6 & 23 \\
\hline Spain & 203 & 66 & 31 & 3 & 19 \\
\hline Austria & 496 & 68 & 29 & 3 & 24 \\
\hline United Kingdom & 257 & 59 & 36 & 5 & 25 \\
\hline Japan & 114 & 67 & 28 & 5 & 26 \\
\hline South Korea & 76 & 75 & 22 & 3 & 18 \\
\hline Finland & 115 & 71 & 29 & 0 & 31 \\
\hline France & 105 & 59 & 39 & 2 & 30 \\
\hline Germany & 119 & 66 & 32 & 2 & 17 \\
\hline Italy & 99 & 61 & 35 & 4 & 29 \\
\hline Sweden & 279 & 57 & 37 & 6 & 20 \\
\hline Czech Republic & 453 & 64 & 31 & 5 & 28 \\
\hline Netherland & 414 & 65 & 31 & 4 & 21 \\
\hline China & 266 & 77 & 18 & 5 & 27 \\
\hline Slovakia & 160 & 57 & 39 & 4 & 22 \\
\hline Turkey & 133 & 69 & 29 & 2 & 32 \\
\hline Turkey & 601 & 69 & 29 & 2 & This study \\
\hline
\end{tabular}

Japanese, Chinese, Czech, Italian, French, Finnish (26-31) and South Korean (18) populations. The frequencies of the mEH exon 4 polymorphism observed in our population were the same as those in the French and German populations and similar to the other populations, listed in Table V. Our results for both exons 3 and 4 genotype frequencies in good agreement with the results of another study carried out in a Turkish population (32). 
Organisms are exposed to epoxide containing compounds from both endogenous and exogenous sources. In mammals, the hydration of these compounds by various epoxide hydrolases not only regulates their genotoxicity, but also, for lipid derived epoxides, their endogenous roles as chemical mediators. Previous findings suggested that epoxide hydrolases as a family represent novel drug discovery targets for the regulation of blood pressure, inflammation, cancer progression and several other diseases (33). In recent years, sEH has attracted attention due to its role in the turnover of lipid derived epoxides, which are signaling lipids with functions in regulatory processes such as the control of blood pressure, inflammatory processes and cell proliferation. Furthermore, sEH is thought to be a promising target for pharmacological inhibition to treat hypertension and possibly other diseases (3).

$\mathrm{mEH}$ classically plays a major role in xenobiotic metabolism and has been described as a biotransformation enzyme. However, mEH also accepts fatty acid-derived epoxides, such as epoxystearic (34) and epoxyeicosatrienoic acids, which are mainly metabolized by sEH (35). Therefore, a role of $\mathrm{mEH}$ in signaling cascades cannot be excluded, particularly in the case of high $\mathrm{mEH}$ expression in certain organs or cell types (3). In light of this knowledge, $\mathrm{mEH}$ and $\mathrm{sEH}$ may complement each other in the breakdown of epoxide derivatives from both exogenous and endogenous sources. This may be of particular importance in individuals with the polymorphic variants of one of these enzymes. Several polymorphisms in human sEH have been identified, including variants with higher (Lys55Arg) and lower (Arg287Gln) epoxide hydrolase activity $(36,37)$. In recent years, case-control studies examining the sEH polymorphisms in different populations and also the association of these polymorphisms with cardiovascular diseases have been published (38-42). However, these studies need to be supported by others carried out in different populations; more research is required to confirm this association and to better understand the mechanisms behind it. On the other hand, we believe that, when evaluating the association of $\mathrm{sEH}$ polymorphisms with diseases, it is important to consider the $\mathrm{mEH}$ polymorphisms of the same individual in order to make a more accurate assessment.

This prompted us to genotype our population for sEH polymorphisms, which are currently under investigation in our laboratory. To our knowledge, there are no studies examining polymorphisms of sEH in a Turkish population. The results of the present study, in conjunction with the results regarding sEH polymorphisms in a Turkish population, provide a framework for further studies concerning the role of these enzymes as a susceptibility factor for hypertension, cardiovascular diseases and cancer.

\section{Acknowledgements}

This work was supported by grant no. T-277 from the Cumhuriyet University CUBAP, Sivas, Turkey.

\section{References}

1. Adams JD Jr, Yagi H, Levin W and Jerina DM: Stereo-selectivity and regio-selectivity in the metabolism of 7,8-dihydrobenzo[a] pyrene by cytochrome P450, epoxide hydrolase and hepatic microsomes from 3-methylcholanthrene-treated rats. Chem Biol Interact 30: 57-77, 1995.
2. Seidegard J and Ekstrom G: The role of human glutathione transferases and epoxide hydrolases in the metabolism of xenobiotics. Environ Health Perspect 4: 791-799, 1997.

3. Decker M, Arand M and Cronin A: Mammalian epoxide hydrolases in xenobiotic metabolism and signalling. Arch Toxicol 83: 297-318, 2009.

4. Szeliga $J$ and Dipple A: DNA adduct formation by polycyclic aromatic hydrocarbon dihydrodiol epoxides. Chem Res Toxicol 11: 1-11, 1998.

5. Szeliga $J$ and Amin S: Quantitative reactions of anti 5,9-dimethylchrysene dihydrodiol epoxide with DNA and deoxyribonucleotides. Chem Biol Interact 128: 159-172, 2000.

6. Seidegard J and DePierre JW: Microsomal epoxide hydrolase. Properties, regulation and function. Biochem Biophys Acta 29: 251-270, 1983.

7. Omiecinski CJ, Aicher L, Holubkov R and Checkoway $\mathrm{H}$ : Human peripheral lymphocytes as indicators of microsomal epoxide hydrolase activity in liver and lung. Pharmacogenetics 3: $150-158,1993$

8. Skoda RC, Demierre A, McBride OW, Gonzalez FJ and Meyer UA: Human microsomal xenobiotic epoxide hydrolase. Complementary DNA sequence, complementary DNA-directed expression in COS-1 cells, and chromosomal localization. J Biol Chem 263: 1549-1554, 1988.

9. Hassett C, Robinson KB, Beck NB and Omiecinski CJ: The human microsomal epoxide hydrolase gene (EPHX1): complete nucleotide sequence and structural characterization. Genomics 23: 433-442, 1994

10. Hassett C, Aicher L, Sidhu JS and Omiecinski CJ: Human microsomal epoxide hydrolase: genetic polymorphism and functional expression in vitro of amino acid variants. Hum Mol Genet 3: 421-428, 1994.

11. Tranah GJ, Chan AT and Giovannucci E: Epoxide hydrolase and $\mathrm{CYP} 2 \mathrm{C} 9$ polymorphisms, cigarette smoking, and risk of colorectal carcinoma in the nurses' health study and the physicians' health study. Mol Carcinog 44: 21-30, 2005.

12. Lin TS, Huang HH, Fan YH, Chiou SH and Chow KC: Genetic polymorphism and gene expression of microsomal epoxide hydrolase in non-small cell lung cancer. Oncol Rep 17: 565-572, 2007.

13. Mittal RD and Srivastava DL: Cytochrome P4501A1 and microsomal epoxide hydrolase gene polymorphisms: geneenvironment interaction and risk of prostate cancer. DNA Cell Biol 26: 791-798, 2007.

14. Lee WJ, Brennan P, Boffetta P, London SJ, Benhamou S, Rannug A, To-Figueras J, Ingelman-Sundberg M, Shields P, Gaspari L and Taioli E: Microsomal epoxide hydrolase polymorphisms and lung cancer risk: a quantitative review. Biomarkers 7: 230-241, 2002.

15. Kiyohara C, Yoshimasu K, Takayama K and Nakanishi Y: EPHX1 polymorphisms and the risk of lung cancer: a HuGE review. Epidemiology 17: 89-99, 2006.

16. Miller SA, Dykes DD and Polesky HF: A simple salting-out procedure for extracting DNA from human nucleated cells. Nucl Acids Res 16: 1215, 1988.

17. Harms C, Salama SA, Torres CHS, Salazar NC and Au WW: Polymorphisms in DNA repair genes, chromosome aberrations, and lung cancer. Environ Mol Mutagen 44: 74-82, 2004.

18. Yim JJ, Park GY, Lee CT, Kim YW, Han SK, Shim YS and Yoo CG: Genetic susceptibility to chronic obstructive pulmonary disease in Koreans: combined analysis of polymorphic genotypes for microsomal epoxide hydrolase and glutathione S-transferase M1 and T1. Thorax 55: 121-125, 2000.

19. Figueras JT, Gené M, Catalán JG, Piqué E, Borrego N Caballero M, Cruellas F, Raya A, Dicenta M and Corbella J: Microsomal epoxide hydrolase and glutathione S-transferase polymorphisms in relation to laryngeal carcinoma risk. Cancer Lett 187: 95-101, 2002.

20. Ahmadi A, Fredrikson M, Jerregard H, Akerback A, Fall PA Rannug A, Axelson O and Soderkvist P: GSTM1 and mEPHX polymorphisms in Parkinson's disease and age of onset. Biochem Biophys Res Commun 269: 676-680, 2000.

21. Van der Logt EMJ, Bergevoet SM, Roelofs HMJ, te Morsche HMR, van Dijk Y, Wobbes T, Nagengast FM and Peters WHM: Role of epoxide hydrolase, $\mathrm{NAD}(\mathrm{P}) \mathrm{H}$ : quinone oxidoreductase, cytochrome P450 2E1 or alcohol dehydrogenase genotypes in susceptibility to colorectal cancer. Mutat Res 593: 39-49, 2006.

22. Židzik J, Slabá S, Joppa P, Kluchová Z, Dorková Z, Skyba P, Habalová V, Salagovič J and Tkáčová R: Glutathione S-transferase and microsomal epoxide hydrolase gene polymorphisms and risk of chronic obstructive pulmonary disease in Slovak population. Croat Med J 49: 182-191, 2008. 
23. Casson AG, Zheng Z, Chiasson D, MacDonald K, Riddell DC, Guernsey JR, Guernsey DL and McLaughlin J: Associations between genetic polymorphisms of Phase I and II metabolizing enzymes, p53 and susceptibility to esophageal adenocarcinoma. Cancer Detect Prev 27: 139-146, 2003.

24. Gsur A, Zidek T, Schnattinger K, Feik E, Haidinger G, Hollaus P, Staudner AM, Armbruster C, Madersbacher S, Schatzl G, Trieb K, Vutuc C and Micksche M: Association of microsomal epoxide hydrolase polymorphisms and lung cancer risk. Br J Cancer 89: 702-706, 2003.

25. Baxter SW, Choong DYH and Campbell IG: Microsomal epoxide hydrolase polymorphism and susceptibility to ovarian cancer. Cancer Lett 177: 75-81, 2002.

26. Takeyabu K, Yamaguchi E, Suzuki I, Nishimura M, Hizawa N and Kamakami Y: Gene polymorphism for microsomal epoxide hydrolase and susceptibility to emphysema in a Japanese population. Eur Respir J 15: 891-894, 2000.

27. Fu WP, Sun C, Dai LM, Yang LF and Zhang YP: Relationship between COPD and polymorphisms of HOX-1 and $\mathrm{mEPH}$ in a Chinese population. Oncol Rep 17: 483-488, 2007

28. Sarmanova J, Benesova K, Gut I, Kristensen VN, Tynkova L and Soucek P: Genetic polymorphisms of biotransformation enzymes in patients with Hodgkin's and non-Hodgkin's lymphomas. Hum Mol Genet 10: 1265-1273, 2001.

29. Sonzogni L, Silvestri L, De Silvestri A, Gritti C, Foti L, Zavaglia C, Bottelli R, Mondelli MU, Civardi E and Silini EM: Polymorphisms of microsomal epoxide hydrolase gene and severity of HCV-related liver disease. Hepatology 36: 195-201, 2002.

30. Clavel J, Bellec S, Rebouissou S, Menegaux F, Feunteun J, Pellie CB, Baruchel A, Kebaili K, Lambilliotte A, Leverger G, Sommelet D, Lescoeur B, Beaune P, Hemon D and Loriot MA: Childhood leukaemia, polymorphisms of metabolism enzyme genes, and interactions with maternal tobacco, coffee and alcohol consumption during pregnancy. Eur J Cancer Prev 14: 531-540, 2005.

31. Laasanen J, Romppanen EL, Hiltunen M, Helisalmi S, Mannermaa A, Punnonen K and Heinonen S: Two exonic single nucleotide polymorphisms in the microsomal epoxide hydrolase gene are jointly associated with preeclampsia. Eur J Hum Genet 10: 569-573, 2002.

32. Ada AO, Suzen HS and Iscan M: Polymorphisms of microsomal epoxide hydrolase and glutathione S-transferase P1 in a male Turkish population. Int J Toxicol 26: 41-46, 2007.

33. Morisseau C and Hammock BD: Epoxide hydrolases: mechanisms, inhibitor designs, and biological roles. Annu Rev Pharmacol Toxicol 45: 311-333, 2005.
34. Zeldin DC, Moomaw CR, Jesse N, Tomer KB, Beetham J, Hammock BD and Wu S: Biochemical characterization of the human liver cytochrome P450 arachidonic acid epoxygenase pathway. Arch Biochem Biophys 330: 87-96, 1996.

35. Oliw EH, Guengerich FP and Oates JA: Oxygenation of arachidonic acid by hepatic monooxygenases. Isolation and metabolism of four epoxide intermediates. J Biol Chem 257: 3771-3781, 1982.

36. Sandberg M, Hassett C, Adman ET, Meijer J and Omiecinski CJ: Identification and functional characterization of human soluble epoxide hydrolase genetic polymorphisms. J Biol Chem 275 28873-28881, 2000.

37. Przybyla-Zawislak BD, Srivastava PK, Vazquez-Matias J, Mohrenweiser HW, Maxwell JE, Hammock BD, Bradbury JA, Enayetallah AE, Zeldin DC and Grant DF: Polymorphisms in human soluble epoxide hydrolase. Mol Pharmacol 64: 482-490, 2003.

38. Fornage M, Boerwinkle E, Doris PA, Jacobs D, Liu K and Wong ND: Polymorphism of the soluble epoxide hydrolase is associated with coronary artery calcification in AfricanAmerican subjects: the Coronary Artery Risk Development in Young Adults (CARDIA) study. Circulation 109: 335-339, 2004.

39. Lee CR, North KE, Bray MS, Fornage M, Seubert JM, Newman JW, Hammock BD, Couper DJ, Heiss G and Zeldin DC: Genetic variation in soluble epoxide hydrolase (EPHX2) and risk of coronary heart disease: the Atherosclerosis Risk in Communities (ARIC) study. Hum Mol Genet 15: 1640-1649, 2006.

40. Burdon KP, Lehtinen AB, Langefeld CD, Carr JJ, Rich SS, Freedman BI, Herrington D and Bowden DW: Genetic analysis of the soluble epoxide hydrolase gene, EPHX2, in subclinical cardiovascular disease in the Diabetes Heart Study. Diab Vasc Dis Res 5: 128-134, 2008.

41. Wei Q, Doris PA, Pollizotto MV, Boerwinkle E, Jacobs DR Jr, Siscovick DS and Fornage M: Sequence variation in the soluble epoxide hydrolase gene and subclinical coronary atherosclerosis: interaction with cigarette smoking. Atherosclerosis 190: 26-34, 2007.

42. Gschwendtner A, Ripke $\mathrm{S}$, Freilinger $\mathrm{T}$, Lichtner $\mathrm{P}$, Müller-Myhsok B, Wichmann HE, Meitinger T and Dichgans M: Genetic variation in soluble epoxide hydrolase (EPHX2) is associated with an increased risk of ischemic stroke in white Europeans. Stroke 39: 1593-1596, 2008 